\title{
The resolution of collective labour disputes in Serbia
}

\begin{abstract}
This article documents the rise of peaceful means of settling collective labour disputes in Serbia. Collective disputes may frequently have a major impact on society and there are clear social benefits in ensuring that the risks of the development of collective disputes are minimised. Describing in detail collective negotiations as a means of the peaceful internal resolution of collective disputes, and the three types in which third parties may be involved in this process (conciliation, mediation and arbitration), the article sets recent developments in Serbia in this direction in their international context. The article also looks briefly at the history of dispute resolution in Serbia, both prior to socialism, during it and afterwards, which the author concludes is a not 'over-rich' one, before describing the legislative steps which Serbia has recently taken and how these might be expected to operate in practice. The author finishes his assessment by reminding us that, as important as taking these steps has been, Serbian society must ensure that they continue to be relevant if they are to be used and to gain weight in the prevention of collective labour disputes.
\end{abstract}

Keywords: collective labour disputes, collective negotiations, third party means, conciliation, mediation, arbitration, history of dispute resolution in Serbia, Agency for the Peaceful Resolution of Labour Disputes.

\section{Introduction}

With the appearance of labour relations (the appearance of capitalism) can be seen the first labour disputes. However, even before that time spontaneous workers' protests were noted although we are aware that collective labour disputes were not differentiated until later. The fundamental condition for the appearance of collective disputes was the strengthening of consciousness amongst workers regarding the substitution of spontaneous and unorganised disputes with mutually-conceived actions for the better protection of their own rights. At that point, the need for collective negotiation, and the real difference between strikes and collective labour disputes, could be felt for the first time. The beginning of the $20^{\text {th }}$ century represents the beginning of the legal organisation of the resolution of collective labour disputes and totally new, specific actions towards their settlement. In this way, collective labour disputes were transferred from the dominion of strike actions into negotiations as the path for the resolution of labour disputes.

A collective labour dispute is a dispute between an employer, or employers in association, on the one hand and the union, as the organisation of workers, on the other regarding the violation or denial of collective rights or workers' interests within 
the labour relationship or the collective organisation of labour relations. A labour dispute could only become collective where it fulfils subjective and objective conditions. It is necessary that more workers in dispute be involved (within the union) and also that there is a need for the dispute to be connected with something which is of collective interest or which refers to workers' rights.

\section{Resolving collective labour disputes}

It is important not to underestimate the significance of individual labour disputes, but it we should emphasise the wider significance that collective labour disputes have for a society. Collective labour disputes, in a great number of cases, either start or end with a strike. Mostly, a great number of workers are involved - or, better said, very often this is the case. The result is that their consequences, especially economic ones, are more noteworthy than those in individual disputes. Strikes, in some particular activities, can provoke issues concerning the security of a country, such as threats to life and health. It is the major reason why each of the participants in a dispute, and each society overall, wants a greater number of collective labour disputes to be resolved before the beginning of a strike, in a peaceful manner.

There exist two fundamental ways for the peaceful resolution of collective labour disputes. The difference lies in the following: the parties in the dispute may resolve the issues by themselves; or, towards the very same solution, external, third party participants might be involved.

The first means is without the participation of a mediator as a neutral party, and through collective negotiation between the employer and the union. It is used very often with simpler disputes where the parties in that dispute estimate that it can be resolved between themselves.

The other means is with the participation of neutral people through conciliation-, mediation- or arbitration-based activities. The difference between these three means of dispute resolution with the participation of a neutral party can be seen in the role that it plays in the very resolution of the dispute.

In practice, it is possible that collective negotiation between the union and the employer is attempted first (in some countries, it is an obligation before the beginning of a strike or lock-out). If it is not successful, conciliation should start with the involvement of a third party in a neutral capacity. Also, it is possible to involve the neutral person immediately, at the very beginning of the negotiations, and prior to negotiations between the parties to the dispute.

Resolving collective labour disputes without the participation of a neutral party (collective negotiations)

Collective negotiations are the means by which the employer and the union seek mutually to organise their relationship.

Such proceedings are mostly regulated by law or collective agreement and the most important foresee the resolution of mutually controversial issues. The resolution of controversial issues by collective negotiation excludes the participation of a third, neutral party.

Negotiation as a method of dispute resolution is the oldest and the most frequent method of resolving collective labour disputes. When a conflict situation starts, it is 
always aimed at resolving the dispute somewhere in the middle of the starting positions, by direct or indirect negotiation between the parties to the dispute.

Collective negotiation has especially large significance in activities of general interest where the parties to the limitations of rights who are on strike are more directed towards this method of dispute resolution.

The procedure for collective negotiation is, to a large degree, devoid of strict formal norms. However, for more successful negotiation and the prevention of misunderstandings and conflicts in the very process of negotiation, it is desirable for the parties in dispute, if this has not already been regulated, to consolidate the rules by which the negotiations will take place.

Collective negotiation mostly takes place in terms of a negotiations committee and is led by representatives from both sides. One of the most important conditions for the successful conclusion of collective negotiation is the quality of the representatives of the parties to the negotiations (the teams).

Each negotiator, as an individual, must have certain qualities, as must the negotiation teams in the round. Besides that, for successful negotiations any conditions that are related to the dispute, or the positions of the parties to it, must be fulfilled.

1. the negotiator must have a clear capability to represent the social group of which he or he is a representative (employer or union). He or she must be professionally qualified (in negotiations and also regarding the particular dispute), experienced, well-acquainted with the issue(s), persistent, tolerant and also prepared for compromise

2. besides the qualities of each individual separately, for successful negotiations the quality of the negotiations team as whole is also a pre-requisite. First of all, the members of the team must co-operate in accomplishing the aim for which it was established. For a successful negotiation team several pre-conditions must be fulfilled:

- mutual aims: all members of the team must have the same aim, understand it and be directed towards its accomplishment

- trust and good mutual relations: members of the team must believe in each other, respect each other and be confident among themselves

- communications: this must be open and sincere.

The negotiations team (the representatives of the team) must have the freedom to negotiate and the authorisation to accomplish the agreement.

3. For the successful termination of collective negotiations, the following optimal pre-conditions for successful negotiation must be fulfilled:

- a low or stable intensity of the dispute; with disputes of a high intensity, it is more complicated to reconcile the attitudes of the parties to the dispute

- the wishes for and acceptance of negotiations from all the parties to the dispute

- the existence of the means (material and non-material) for the fulfilment of at least a certain degree of the interests of the parties to the dispute

- relatively small differences between the strengths of the parties to the dispute.

Even in practice, collective negotiation makes out its own case in which the usual and most frequent phases can be seen as follows:

- preparation for negotiation

- beginning of negotiation

- exposure of the initial (maximised) requests 
- reaction of the other party to the requests made

- exposition of the more real (lesser) requests

- achievement of compromise

- ratification of the agreement.

Looking at the picture in the round, it can be concluded that collective negotiation is a very suitable method for resolving collective labour disputes and, therefore, that the parties to the dispute should be encouraged to resolve their issues in this manner. With this in place, we will not only nip strikes and disturbances in the bud but, after a dispute is resolved in this manner, the mutual trust of the social partners is strengthened and, with this, the possibility of other disputes in the future are lessened.

Today, collective negotiation as a method for resolving collective labour disputes is used all over the world. It is especially used as the dominant manner for resolving collective disputes in Scandinavian and Anglo-Saxon countries, as well as in France.

In France, on the basis of the Law on labour disputes from 1950, collective negotiation is used in a basic and obligatory manner for resolving collective disputes.

In the UK, collective negotiations regarding collective labour disputes has been used from as far back as the second half of the $19^{\text {th }}$ century via joint boards for conciliation and arbitration as the prior method of resolving disputes. Similar boards continue to exist for resolving collective disputes.

The furthest along the path of collective negotiation has been attained by Scandinavian countries. In Sweden, by basic collective agreement from 1938, unions and employers are prohibited from undertaking direct action (strikes and lock-outs) before negotiations have started. In these countries, the so-called neo-corporatist approach still stands (the aiming at consensus between all the important social partners regarding important social decisions).

\section{Resolving collective labour disputes with the participation of a neutral person}

One method of dispute resolution, the resolving of collective labour disputes with the participation of a neutral party is used either directly after the beginning of a dispute, or after an unsuccessful attempt at collective negotiation between the union and the employer.

Theory and practice demonstrate three modalities of this manner for resolving collective labour disputes, i.e. in the following ways: conciliation, mediation and arbitration.

The difference can be seen in the degree of participation and the role that the third, neutral party plays in the proceedings for resolving the labour dispute. That role is at its most passive with conciliation while it is at its most active with arbitration. Some countries provide within their legal system each of these three modalities, which are used depending on the type of labour dispute and the wishes of the parties, while some legal systems retain just one of these modalities for resolving collective disputes. In addition, there are countries that do not make a difference between conciliation and mediation (Sweden, Great Britain, USA, Serbia ...).

\section{Conciliation}

Conciliation is a procedure for resolving collective disputes in a peaceful way, where a neutral party (drawn from a board of individuals) provides help to the parties in a dispute with the aim of helping them resolve the problem. Conciliation offers the lightest touch of neutral intervention, since conciliators have the task only of making 
it easier to find a resolution, not of finding one by themselves. Conciliators do not have any real power to decide or impose their own will on the parties to a dispute. The main - and really the only - means that they have at their disposal is diplomatic skill and a capacity to persuade.

Conciliation between the parties to a dispute is a very popular method for resolving disputes; the small amount of external influence means that the parties can not lose too much but can gain significantly. Therefore, conciliation exists in many countries as a pre-condition before strikes and lock-outs.

Conciliation has been present from the beginnings of capitalism, but it has prospered and achieved its current form with the appearance of unions and the first collective agreements (France, New Zealand, Holland, Canada, etc.).

In practice, many models of conciliation exist of which the most important are:

- whether the obligation should exist on a voluntary or a mandatory basis

- whether conciliation bodies should exist on an ad hoc or a permanent basis.

Conciliation has its biggest influence on conflicts which have a special significance (conflicts in activities of a general interest, covering a large area or at the sector-wide level: collective labour disputes in this direction can have major consequences for society, so need to be avoided). To prevent that, many legislatures have a pre-condition for conciliation before the beginning of a strike (USA, Japan, Finland).

\section{Mediation}

Mediation is a method of resolving collective disputes in which the neutral party provides active help to the parties with the aim of finding a solution, or suggesting one to them as some kind of recommendation if they are unable to find a compromise. Mediation as a manner for resolving collective disputes lies between conciliation and arbitration, and represents a combination of them both. A mediator familiar with mediation techniques tries first to reconcile the parties to the dispute and, if unsuccessful in this, delivers a recommendation which, if accepted, has a similar influence to arbitration decisions.

Mediation plays a significant part in resolving collective labour disputes as a result of the characteristics that it has. A large number of disputes, because of their nature, require active neutral intervention in some form of conciliation. However, looking at the picture in terms of geography, mediation is less present than conciliation and arbitration. Mostly, it is used in the USA (Federal Mediation and Conciliation Service), Greece (Mediation and Arbitration Service - OMED), France, Belgium and Scandinavian countries.

In the legal context, mediation was developed later than conciliation. Mediation as a separate method for resolving collective disputes was developed when, regarding the numerous disputes that could not be resolved by conciliation and arbitration, a need was identified for a special method that, by its degree of external intervention, was at the interstices of conciliation and arbitration.

Just the same as conciliation, mediation is envisaged in many countries (by collective agreement or by the law) as prohibiting lock-outs or strikes while it is taking place so as to ensure that mediators can undertake their work undisturbed. 
In practice, no two mediations are the same but we can see that there are three basic phases of mediation:

- insight into the dispute questions and the establishment of their causes

- attempts at compromise

- delivering a recommendation.

Mediation can be concluded in two ways: by reaching a compromise between the parties to the dispute or by drawing up a recommendation. The rule is usually that the recommendation of the mediator is not binding on the parties to the dispute although, exceptionally, there are cases in which the recommendation of the mediator is binding (for example, Austria).

\section{Arbitration}

Arbitration is a procedure for resolving collective labour disputes in which a neutral arbitrator, engaged with the assistance of the parties to the dispute, delivers a decision on the basis of which the dispute may be resolved. The basic aim of arbitration, as with conciliation and mediation, is the avoidance of the cessation of labour (via a strike or a lock-out).

Arbitration has many similarities to conciliation and mediation: it is a peaceful and extrajudicial method of resolving disputes, handing the dispute over to a neutral third party and where the proceedings are marked by informality and speed of decision-making. However, the differences are not negligible. The basic characteristic of arbitration, in contrast to conciliation and mediation, is the greater influence played by the intervention of the third party, since the arbitrator individually provides a decision for resolving the dispute. With conciliation and mediation, the centre of activity lies with the parties who are in dispute, whereas in arbitration the arbitrator is the key person in the resolution of the dispute. The result in practice is that arbitration is mostly used when conciliation and/or mediation have been shown as inefficient means for resolving the specific dispute.

Regarding the formality of the proceedings, arbitration is more formal than conciliation and mediation, and even encompasses some elements of legal proceedings. However, even though it has a quasi-juridical character, arbitration is incomparably simpler and more informal than legal proceedings.

In practice, an arbitration procedure has, for the most part, two basic phases:

- insight into the questions of the dispute and research into its causes

- reaching a decision.

For a better quality solution to a dispute, the arbitrator must be competent and have freedom of decision-making. The bigger role in the procedure compared to that of a conciliator or a mediator means that the choice of an arbiter is subject to tougher criteria. From him or her is asked total independence and impartiality. He or she has to be equitable, respectable and a good diplomat. In almost all countries, he or she must have a high level of education. Very often, the conditions for an arbitrator are the same as for judges: for example, the members of the Australian Conciliation and Arbitration Commission (now the Australian Industrial Relations Commission) had to have five years of experience in advocacy or else they had to be High Court judges.

Furthermore, the written decisions of the arbitrator must be clear and understandable. 


\title{
Resolving collective labour disputes within our existing legislature
}

\author{
History
}

Peaceful methods for resolving collective labour disputes do not have an over-rich history in Serbia. The period before the First World War is characterised by our country lagging behind world growth trends and possessing a pre-capitalist economy. The working class was neither numerous nor organised: barely by the end of the $19^{\text {th }}$ century and the beginning of the $20^{\text {th }}$ was the labour movement formed in Serbia, following the appearance of Svetozar Marković. The first norms regarding the resolution of collective labour disputes can be seen in the Rotary law from 1883, under which conflicts between industrials and participants were resolved in front of a rotary assembly but which, in practice, did not have wider influence.

The period between the two world wars was characterised by a contestation of the right to strike as the basic condition for the successful resolution of collective labour disputes. Officially the strike was neither known nor forbidden although, in contrast, the lock-out was legally acknowledged and permitted. Conciliation was mentioned in some collective agreements. From 1937, when conciliation and arbitration were regulated, started the obligation of the parties to a dispute to address the authorised administration (the administrative district) in an attempt at conciliation prior to the commencement of a strike or lock-out.

After World War II, subsequent to the installation of socialism, the institutions and mechanisms that are the attribute of a market economy were lost as, therefore, were the basics of conciliation, mediation and arbitration. Our country is rated alongside those that did not acknowledge the right to strike. The first regulation in the area of resolving collective labour disputes was the Code of the work of arbitration commissions in the proceedings of tariff regulation for economic organisations from 1955. That Code foresaw boards of arbitration for dispute resolution. The Law on labour relations from 1957 foresaw the possibility of arbitration in disputes regarding the disagreement of the union committee with the suggestions under the Code of labour relations brought by the labour council. It envisaged arbitration regarding the resolution of controversial issues on the conclusion and achievement of collective agreements in the private sector. The Law on joint work played a special part, under the name 'Resolution of disputes that could not be resolved in a regular manner' which foresaw special activity for resolving collective labour disputes. This was not respected and was, therefore, abandoned with the idea of self-management. With the amendment to the Constitution of SFRJ in 1988, the right to strike was acknowledged and this was continued in the actual Constitution of Serbia. With this, our society was ready to continue on the road towards the organisation of the collective resolution of labour disputes. This was done in 2004, with the Law on the peaceful resolution of labour disputes.

\section{Positive-legal aspects}

Today, the resolution of collective labour disputes in Serbia falls within the Law on labour, the Law on the peaceful resolution of labour disputes and several collective agreements.

The Law on labour regulates the rules under which controversial questions regarding disputes over, changes and additions to, and the use of collective agreements may be resolved by arbitration. The composition, means of operation and the effects 
of the decision depend on the type of dispute, apropos whether it is interest-based or legal arbitration. Interest-based arbitration is used in the resolution of disputes related to collective agreements, as in the case of changes and additions to collective agreements. In this case, the composition, means of operation and the effects of the decision are, by their common consent, determined by the signatories to the collective agreement. Legal arbitration consists of arbitration for resolving disputes over the use and interpretation of a collective agreement in which the composition, means of operation and effects of the decision are already determined within the collective agreement. Legal arbitration decisions are binding on the parties to a dispute, whereas interest-based arbitration decisions depend on the decisions of the participants in discussions over collective agreements.

The Law on the peaceful resolution of labour disputes is the first act in our legislature that, in a complete manner, organises the regulation of the peaceful resolution of labour disputes. Otherwise, it falls under a law that makes no differentiation between conciliation and mediation. Therefore, within this concept, conciliation is envisaged as constituting what is, to all intents and purposes, mediation. In addition to individual labour disputes, it envisages the possibility of resolving collective labour disputes by conciliation (mediation). 'Collective labour disputes' in the sense of this law encompasses disputes regarding discussions over, changes and additions to, and the use of collective agreements as regards both the right to strike and union organising.

The Law on the peaceful resolution of labour disputes envisages that collective labour disputes may be resolved with the help of a conciliator appointed on the basis of agreement between the parties to the dispute from amongst the Register of elected conciliators and arbitrators. If the parties to a dispute can not agree on the conciliator, this is determined by the manager of the Agency for the Peaceful Resolution of Labour Disputes of the Republic of Serbia. Conciliation is carried out in front of a conciliation committee, which is made of representatives from each of the parties to the dispute and the conciliator, who is the president of the committee. At the termination of the proceedings, the committee brings a written recommendation regarding the manner of the resolution of the dispute which has effect if all committee members vote for it. If the committee does not reach a recommendation within thirty days, the conciliator can suggest a recommendation to the parties to the dispute which is not binding on them. However, if the parties accept the recommendation, the agreement on the resolution of the dispute is concluded. If the subject of the dispute is the collective agreement, the agreement becomes its component, giving the agreement the potential for legal adjustment.

The Law on the peaceful resolution of labour disputes increases the possibility of the participation of conciliators in collective negotiation proceedings, a situation which should further the aim of the prevention of the rise of disputes. The task of the conciliator is to be present during negotiations, show the parties in negotiation suggestions that may be made notwithstanding the law and give professional help to the parties to the negotiations.

\section{Conclusion}

Collective labour disputes present one type of illness in society. They provoke major disturbances not only in the company where they occur but very often in other areas. 
Collective labour disputes in particular activities, across a large area or a whole economic sector can engender disturbances to the economy of any country and jeopardise its security, as well as the life and health of its people. Therefore, each society wants to prevent those conflicts or to minimise them. The identification of the causes of conflict needs to carried out so that these may be prevented. At the same time, there is a need for instruments to be adopted and developed that would help such disputes, if they occur, to be resolved in a peaceful manner before the arrival of these consequences. Such instruments are collective negotiations, conciliation, mediation and arbitration.

In 2004, with the Law on labour and the Law on the peaceful resolution of labour disputes, Serbia made a major effort towards the organisation and popularisation of such instruments. In doing so, it surmounted the large gap that existed between our legislature and the legislature in the rest of the developed world. However, we should not stop there. It is necessary that these be permanently adjusted to the requirements of the situation, and improved, in line with the views of the representatives of unions and employers. Furthermore, it is important that we point out the benefits of this type of collective labour dispute resolution.

\section{References}

Brković, Radoje Labour court.

Jašarević, Senad Resolution of labour disputes by peaceful means in theory and practice.

Lubarda, Branko Resolution of collective labour disputes.

Šunderić, Borivoje Resolution of disputes regarding the conclusion and use of collective agreements.

Marinković, Darko (2005) Industrial relations Megatrend University, Belgrade. 